
університету. - Серія "Регіональна економіка". - Випуск 16 (63). - Редкол.: відп. ред. д.е.н., професор Л.Л. Ковальська - Луцьк : ІВВ Луцького НТУ, 2019. -173 с.

УДК 338.48:332.14(477)

Матвійчук Л.Ю., д.е.н., професор

Луцький національний технічний університет

\title{
СТРУКТУРНА МОДЕРНІЗАЦІЯ ТУРИСТИЧНОЇ ГАЛУЗІ РЕГІОНУ ШЛЯХОМ ВПРОВАДЖЕННЯ СМАРТ-СПЕЦІАЛІЗАЦІЙ
}

У статті проаналізовано потенціал концепції смарт-спеціалізації та напрями іiі застосування для розвитку туристичної галузі регіону. Проведено аналіз наявного потенціалу туристичної галузі з метою визнання оптимальних напрямів запровадження смарт-спеціалізацій.

Ключові слова: смарт-спеціалізація, туризм, регіональний розвиток, модернізація галузі.

Matviichuk L.

\section{STRUCTURAL MODERNIZATION OF THE TOURIST BRANCH OF THE REGION BY THE IMPLEMENTATION OF SMART SPECIALIZATIONS}

The directions of tourism development on the basis of smart specialization are grounded. The analysis of the existing potential of the tourism industry is conducted in order to recognize the optimal directions of introduction of smart specializations.

The prerequisites for the successful introduction of smart specializations in the region, which include: promotion of tourist sites, creating a platform for communication with potential users of tourist services, identifying target audiences, ensuring the safety of tourists, implementing practical training for administrative resources at tourist sites, setting up proper communication with representatives of the united territorial communities in the field of tourism, definition of a clear concept of development of a network of routes of active tourism.

The European experience in the introduction of smart specializations is analyzed. It proves that it is important to consider tourism not as an area in the shadow of the industrial sector, but as an integral part of the regional innovation system and an element of knowledge economy development in the region. The inefficiency in the current conditions of the tourism development strategy, which is based solely on the principles of the use of cultural and natural resources, has been proved.

On the basis of the analysis of the existing conditions of regional development, due to the conducted SWOT-analysis of the tourist industry of the region, the competitive advantages and limitations of the prospective development 
Економічні науки: збірник наукових праџь Луцького національного технічного університету. - Серія "Регіональна економіка". - Випуск 16 (63). - Редкол.: відп. ред. д.е.н., професор Л.Л. Ковальська - Луцьк : ІВВ Луцького НТУ, 2019. -173 с.

of the studied area were determined. Priority directions for the introduction of smart specializations are identified, which include the formation of a digital archive of cultural heritage monuments of the region, the development of $3 \mathrm{D}$ routes of historical and architectural monuments, the creation of $3 \mathrm{D}$ models of castles and palaces of the region, the introduction of QR-coding of tourist attractions of the region and more.

It is proved that the conceptual policy of smart specialization is the process of mobilizing the competitive advantages of the tourism industry of the region, priorities and scientific potential. The identified areas of smart specialization of the tourism industry of the region will accelerate the pace of structural modernization of the industry, increase its competitiveness and expand the range of tourism services offered.

Key words: smart specialization, tourism, regional development, industry modernization.

Матвийчук Л.Ю.

\section{СТРУКТУРНАЯ МОДЕРНИЗАЦИЯ ТУРИСТИЧЕСКОЙ СФЕРЫ РЕГИОНА ПУТЕМ ВНЕДРЕНИЯ СМАРТ- СПЕЦИАЛИЗАЦИЙ}

В статье проанализированы потенциал концепции смартспециализации и направления ее применения для развития туристической отрасли региона. Проведен анализ имеющегося потенциала туристической отрасли с целью признания оптимальных направлений внедрения смартспециализаций.

Ключевые слова: смарт-специализация, туризм, региональное развитие, модернизация отрасли.

Постановка проблеми у загальному вигляді та ії зв'язок 3 важливими науковими та практичними завданнями. Доцільність удосконалення політики туристичного розвитку в регіонах обумовлена зміною глобальних трендів економічного розвитку та вичерпанням потенціалу традиційних чинників зростання конкурентоспроможності регіонів у національному та світовому масштабах. Такою моделлю регіонального та міжрегіонального партнерства, що має значний потенціал забезпечення сталого розвитку регіонів України 3 визначенням туристичних пріоритетів іiі впровадження є смартспеціалізація регіонів. 
Економічні науки: збірник наукових праџь Луцького національного технічного університету. - Серія "Регіональна економіка". - Випуск 16 (63). - Редкол.: відп. ред. д.е.н., професор Л.Л. Ковальська - Луцьк : ІВВ Луцьккого НТУ, 2019. -173 с.

Аналіз останніх досліджень, у яких започатковано вирішення проблеми. Серед наукових робіт, присвячених питанням регіональної смарт-спеціалізації туристичної сфери слід відмітити праці БіланюкО.П., Мальської М.П., Снігової О.Ю., Шульц С.Л. та ін., в яких визначені основні концептуальні положення смарт-спеціалізації та наведені рекомендації 3 їх впровадження. Водночас, потребують подальшого дослідження методологія та практичні аспекти смарт-спеціалізації регіонів в галузі туризму.

Цілі статті. Метою дослідження є наукове обгрунтування можливих шляхів ефективної модернізації туристичної галузі шляхом, впровадження смарт-спеціалізацій та забезпечення ефективної діяльності суб' єктів туризму на рівні регіону.

Виклад основного матеріалу дослідження 3 повним обгрунтуванням отриманих наукових результатів. Успіх розвитку туристичної галузі регіону багато в чому зумовлений істотними структурними змінами та визначених чітких напрямів діяльності а, отже, для забезпечення динамічного розвитку слід переглянути наявні структури такого розвитку з врахуванням зростаючого впливу зовнішніх та внутрішніх факторів, а також поширення інновацій в галузі [2].

Загалом, смарт-спеціалізація - це підхід Європейської комісії до визначення пріоритетів інноваційного розвитку територій. Україна розпочала процес впровадження цього підходу у 2016 році. Застосування смарт-спеціалізацій туристичного спрямування в регіоні передбачає аналіз економічного, інноваційного та наукового потенціалу регіону, а також обговорення на підставі проведеного аналізу 3 представниками туристичного бізнесу громадськості, науки та місцевої влади, що саме може бути пріоритетами інноваційного розвитку регіону, базуючись на його сильних сторонах i доступних ресурсах.

Європейський досвід доводить, що важливо розглядати туризм не як сферу, що перебуває в тіні промислового сектору, а як невід'ємну складову регіональної інноваційної системи та елемент розвитку економіки знань у регіоні. Безперспективною 
Економічні науки: збірник наукових праџь Луцького національного технічного університету. - Серія "Регіональна економіка". - Випуск 16 (63). - Редкол.: відп. ред. д.е.н., професор Л.Л. Ковальська - Луцьк : ІВВ Луцького НТУ, 2019. -173 с.

в сучасних умовах є стратегія розвитку туризму, що базується виключно на засадах використання культурних i природних ресурсів [4].

Структурна модернізація туристичної галузі шляхом впровадження смарт-спеціалізацій передбачає формування чіткого бачення перспективних напрямів розвитку регіону. Для цього, при формуванні регіональних стратегій, доцільно дати відповіді на кілька ключових питань:

1. Яку конкурентну позицію планується отримати в контексті туристичного середовища регіону?

2. Якого типу соціально відповідальну спільноту є намір побудувати?

3. Який рівень захисту довкілля потрібно забезпечити в результаті туристичної діяльності?

4. Наскільки розумною та інноваційною може стати туристична галузь в регіоні?

Чітке розуміння ключових напрямів регіонального розвитку дозволяє швидше та ефективніше досягнути бажаних результатів впроваджених смарт-спеціалізацій, які повинні базуватися на ретельному аналізі регіональної економіки, суспільства та структури інноваційної діяльності. Метою такого аналізу $є$ водночас оцінка вже існуючих ресурсів регіону та перспектив щодо їх подальшого розвитку. Спільним та ключовим аспектом аналізу є перехід до широкого погляду на інноваційну складову регіонального розвитку. Зважаючи на зазначене, доцільно провести аналіз туристичного потенціалу регіону. Пропонуємо здійснити такий аналіз на прикладі Волинської області.

Володіючи широким спектром туристичних ресурсів, потужним людським капіталом та маючи перспективне геостратегічне розташування, Волинська область досі не змогла належним чином скористатися цими можливостями для досягнення збалансованого туристичного розвитку, а фрагментарність використання наявного туристичного потенціалу супроводжувалася посиленням регіональних диспропорцій [5]. 
Економічні науки: збірник наукових праць Луиького національного технічного університету. - Серія "Регіональна економіка". - Випуск 16 (63). - Редкол.: відп. ред. д.е.н., професор Л.Л. Ковальська - Луцьк : ІВВ Луцького НТУ, 2019. -173 с.

Волинська область, зважаючи на їі багатовікову історію та багаті традиції, вирізняється своєю самобутністю, тому розвиток туризму на цій території надзвичайно перспективний. Так, на території області доцільно розвивати подієвий, спортивний, рекреаційний, велосипедний, водний, сільський зелений туризм. Туризм часто передбачає певний пізнавальний складник, тобто залучення туристів до місцевої культури. У таблиці 1. представлено туристичні потоки Волинської області в період з 2000 року по 2018 рік [1].

Таблиця 1

Туристичні потоки Волинської області

\begin{tabular}{|c|c|c|c|c|}
\hline \multirow{2}{*}{} & \multirow{2}{*}{$\begin{array}{c}\text { Кількість } \\
\text { туристів, } \\
\text { усього }\end{array}$} & $\begin{array}{c}\text { Ізоземні } \\
\text { туристи }\end{array}$ & $\begin{array}{c}\text { громадяни України, } \\
\text { які виїжджали за } \\
\text { кордон }\end{array}$ & $\begin{array}{c}\text { внутрішні } \\
\text { туристи }\end{array}$ \\
\hline 1 & 2 & 3 & 4 & 5 \\
\hline 2000 & 73126 & 1793 & 3299 & 68034 \\
\hline 2001 & 47819 & 520 & 1768 & 45531 \\
\hline 2002 & 60701 & 2138 & 4170 & 54393 \\
\hline 2003 & 60945 & 2479 & 3870 & 54596 \\
\hline 2004 & 58239 & 3665 & 5976 & 48598 \\
\hline 2005 & 57319 & 3433 & 8983 & 44903 \\
\hline 2006 & 64254 & 4083 & 8137 & 52034 \\
\hline 2007 & 68687 & 5103 & 10246 & 53338 \\
\hline 2008 & 67044 & 5826 & 7796 & 53422 \\
\hline 2009 & 45674 & 3357 & 5784 & 36533 \\
\hline 2010 & 52041 & 4021 & 7740 & 40280 \\
\hline 2011 & 14657 & 1193 & 5881 & 7583 \\
\hline 2012 & 19789 & 991 & 8312 & 10486 \\
\hline 2013 & 19490 & 1095 & 12019 & 6376 \\
\hline 2014 & 14593 & 349 & 8073 & 6171 \\
\hline 2015 & 15620 & 645 & 9327 & 5648 \\
\hline 2016 & 26526 & 486 & 19446 & 6594 \\
\hline 2017 & 17047 & 679 & 12429 & 3939 \\
\hline 2018 & 18005 & 703 & 13121 & 4181 \\
\hline
\end{tabular}


Економічні науки: збірник наукових праџь Луцького національного технічного університету. - Серія "Регіональна економіка". - Випуск 16 (63). - Редкол.: відп. ред. д.е.н., професор Л.Л. Ковальська - Луцьк : ІВВ Луцьккого НТУ, 2019. -173 с.

Найбільша кількість туристів за досліджуваний період припадає на 2000 р. - 73126 осіб. У 2018 р., порівняно з 2000 р., загальна кількість туристів зменшилась на 55121 осіб (на $75,4 \%$ ). Найменша кількість туристів у Волинській області припадає на 2014 р. - 14593 особи. Зауважимо, що в цілому, за останні два роки загальна кількість туристів має тенденцію до збільшення.

Основу туристичних потоків до області складають виїзні туристи - $73 \%$; у 2,9 разів менше внутрішніх туристів - $25 \%$; найменшу частку становлять іноземні туристи $-2 \%$.

Найбільшою популярністю серед виїзних туристів Волинської області у 2018 р. користувались Польща, Туреччина, Сгипет, Болгарія. Найпотужнішими туристичними центрами у області залишаються Шацькі озера та м. Луцьк.

Для ефективного застосування смарт-спеціалізацій туристичної галузі в регіоні доцільним є утворення комплексу, який об'єднуватиме органи державної влади на рівні місцевого самоврядування в особі їх представників, турфірми, організації, підприємства, навчальні та наукові заклади, особи, зайняті у сфері організації тих чи тих туристичних подій в області для формування конкурентоспроможних туристичних продуктів регіону [3].

Передумовами успішного запровадження смартспеціалізацій в регіоні є: промоція туристичних об'єктів, створення платформи для комунікації 3 потенційними користувачами туристичних послуг, визначення цільових аудиторій, забезпечення безпеки туристів, запровадження практичних тренінгів для адмінресурсу на туристичних об'єктах, налагодження правильної комунікації 3 представниками об'єднаних територіальних громад у сфері туризму, визначення чіткої концепції розвитку мережі шляхів активного туризму.

Крім того, однією з важливих передумов візитів туристів до Волинської області виступає проведення міжнародних заходів, зокрема, у регіоні періодично проводиться велика кількість фестивалів. Серед спектра подій, на яких грунтується 
Економічні науки: збірник наукових праџь Луцького національного технічного університету. - Серія "Регіональна економіка". - Випуск 16 (63). - Редкол.: відп. ред. д.е.н., професор Л.Л. Ковальська - Луцьк : ІВВ Луиького НТУ, 2019. - 173 с.

розвиток туризму Волині, можна назвати такі: економічні, громадські, мистецькі, спортивні заходи, культурно-історичні театралізовані шоу [8].

На основі аналізу сильних та слабких сторін розвитку туризму у Волинській області проведемо SWOT-аналіз такого розвитку (таблиця 2).

Аналіз сильних і слабких сторін, стану та перспектив розвитку туризму у Волинській області, підтверджує необхідність активних дій, перш за все з боку регіональних органів влади, а також держави, спрямованих на створення умов динамічного розвитку туризму в регіоні, фінансування такого виду економічної діяльності, а також просування регіональних турпродуктів на ринку туристичних послуг.

Отримана в результаті проведеного аналізу інформація може слугувати інструментом, на основі якого регіон зможе розробити свої пріоритети. Ключовими особливостями смартспеціалізації є їі обгрунтованість та доказовість. Перед тим, як обирати пріоритет смарт-спеціалізації, потрібно чітко розуміти кількісні та якісні показники туристичного потенціалу регіону.

Смарт-спеціалізація туристичної галузі передбачає залучення різних видів та рівнів стейкхолдерів до активної участі в розробці іiі дизайну та подальшій імплементації. Наявність чіткого та спільного бачення регіонального туристичного розвитку має вирішальне значення для утримування інтересу з боку стейкхолдерів різних типів.

Основною умовою структурної модернізації туристичної галузі $є$ задоволення потреб туристів та гарантування безпеки туризму. У зв'язку 3 тим, що, туризм $\epsilon$ міжгалузевим господарським комплексом регіону, який спеціалізується на виробництві та реалізації якісного туристичного продукту суб'єктами туристичної діяльності, здатного задовольняти специфічний попит туристів, визначена смарт-спеціалізація має враховувати зазначені фактори регіону [6]. 
Економічні науки: збірник наукових праџь Луцького національного технічного університету. - Серія "Регіональна економіка". - Випуск 16 (63). - Редкол.: відп. ред. д.е.н., професор Л.Л. Ковальська - Луцьк : ІВВ Луиького НТУ, 2019. -173 с.

Таблиця 2

Матриця SWOT-аналізу розвитку туризму у Волинській області

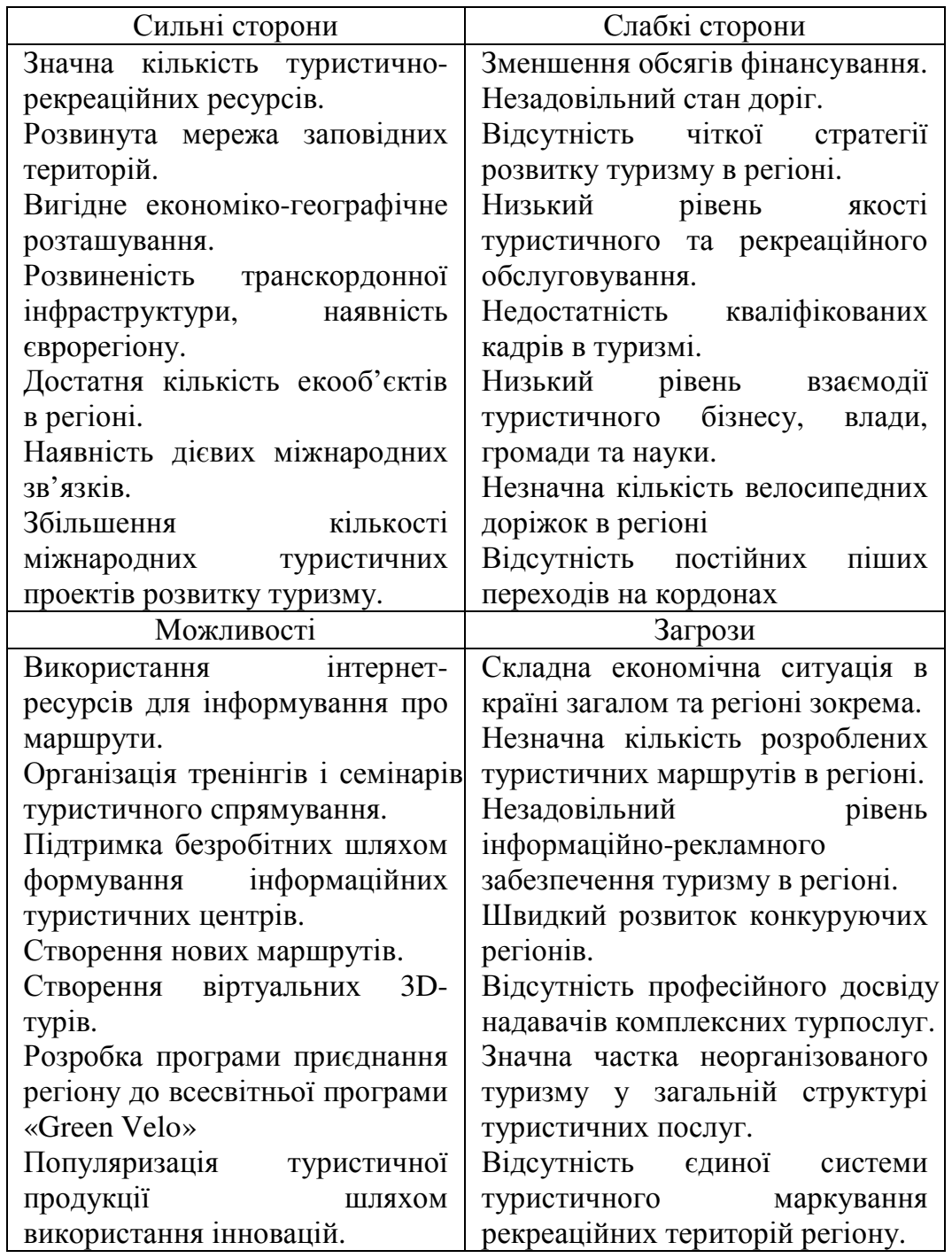


Економічні науки: збірник наукових праџь Луцького національного технічного університету. - Серія "Регіональна економіка". - Випуск 16 (63). - Редкол.: відп. ред. д.е.н., професор Л.Л. Ковальська - Луцьк : ІВВ Луцьккого НТУ, 2019. -173 с.

Зважаючи на зазначене в регіоні доцільно впроваджувати такі туристичні інновації як: формування цифрового архіву пам'яток культурної спадщини регіону, розробка 3 D маршрутів історико-архітектурних пам'яток, створення 3 D моделей замків та палаців області, запровадження QR-кодування туристичних атракцій регіону тощо.

Впровадження смарт-спеціалізації туристичної галузі в регіоні має формується у відповідності із принципами поєднання процесів глобалізації та локалізації, інтеграційної політики кластеризації, посилення транскордонних взаємодій в межах системи «туристичний бізнес-наука-громадськість», збереження ресурсів та можливостей їх найефективнішого застосування. Концептуальна політика смарт-спеціалізації $\epsilon$ процесом мобілізації конкурентних переваг туристичної сфери регіону, пріоритетів та максимізації нереалізованого наукового.

Висновки. На основі аналізу наявних умов регіонального розвитку, завдяки проведеному SWOT-аналізу туристичної галузі регіону визначені конкурентні переваги та обмеження перспективного розвитку досліджуваної сфери. Визначено пріоритетні напрямки впровадження смарт-спеціалізацій до яких віднесено: формування цифрового архіву пам'яток культурної спадщини регіону, розробка 3 D маршрутів історикоархітектурних пам'яток, створення 3 D моделей замків та палаців області, запровадження QR-кодування туристичних атракцій регіону тощо.

Концептуальна політика смарт-спеціалізації $є$ процесом мобілізації конкурентних переваг туристичної сфери регіону, пріоритетів та наукового потенціалу. Визначені напрями смартспеціалізації туристичної галузі регіону дозволить пришвидшити темп структурної модернізації галузі, підвищить iii конкурентоспроможність та розширить спектр запропонованих туристичних послуг.

1.Головне управління статистики у Волинській області [Електронний pecypc]. Режим доступу: http://www.lutsk.ukrstat.gov.ua.

2.Регіональна структурна політика: сучасні тенденції та нові виклики : монографія / ДУ «Інститут регіональних досліджень імені М.. Долішнього 
Економічні науки: збірник наукових праць Луиького національного технічного університету. - Серія "Регіональна економіка". - Випуск 16 (63). - Редкол.: відп. ред. д.е.н., професор Л.Л. Ковальська - Луцьк : ІВВ Луцького НТУ, 2019. -173 с.

НАН України» ; наук. ред. С.Л. Шульц ; С.Л. Шульц, С.Й. Вовканич, C.М. Писаренко, М.В. Максимчук, О.М. Луцків, та ін. Львів, 2016., 328 с.

3.Прокопюк А. Методологічні засади та напрями реалізації державної структурної політики. Вісник Сумського національного аграрного університет. Сумський національний аграрний університет. Суми, 2016. Випуск 2 (56). C. 82-99.

4.Мальська М.П., Біланюк О.П. Концепція смарт-спеціалізації як методологічна основа розвитку транскордонних туристичних ринків. Регіональна економіка. 2018. №2(88). С. 39-43.

5.Матвійчук Л.Ю. Сільський зелений туризм як фактор регіонального розвитку: методологічний аспект та практичний досвід: монографія. Луцьк: РВВ Луцького НТУ, 2017. 260 с.

6.Моісєєва Н.I. Інноваційний розвиток туристичної сфери регіону: теорія, методологія, практика. Миколаїв. ФОП Швець В.М. 2018. 330 с.

7.Снігова О.Ю. Розкриття потенціалу смарт-спеціалізації для подолання регіональної структурної інертності в Україні // Економіка України. 2018. №8. С. 75-88.

8.Черчик Л.М. Сучасний стан розвитку туристично-рекреаційного комплексу Волинської області: Монографія. Луцьк: Східноєвропейський національний університет імені Лесі Українки, 2014. 152 с. 